\title{
Fellowship at orita: A critical analysis of the leadership crisis in the Assemblies of God, Nigeria
}

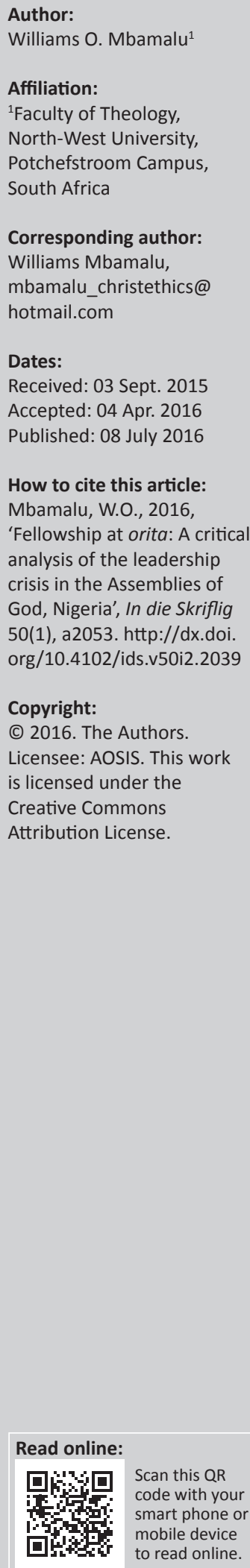

This article is a critical analysis of the present crisis in the Assemblies of God, Nigeria (AGN). A background history of the church is given to show how growth had taken place and how decline had set in. Doing this involves analysing the factors responsible for the present crisis that has brought the church to its knees. The article finds that the AGN's membership and leadership are dominated by the Igbo ethnic group whose worldviews are known to be highly competitive, individualistic and 'pantomimic'. The AGN's constitution and bye-laws do not include a clause that prevents pastors from the same ethnic group from holding the two top-most positions of the General Superintendent and the Assistant General Superintendent at the same time. Therefore the article submits that the AGN should amend its constitution to deal with these pertinent issues. The significance of the article is that it calls the attention of other Pentecostal denominations in Nigeria and the rest of Africa to the crisis-ridden AGN, whose eschatological and Pentecostal persuasion is at orita [the crossroads] and urges them to learn from it.

\section{Introductory background story of the Assemblies of God, Nigeria}

The story is everlasting like Fire, when it is not blazing it is smouldering under its own ashes or sleeping and resting inside its flint house. When we were young and without experience, we all imagined that the story of the land is easy, that anyone of us can get up and tell it. But that is not so. True, we all have our little scraps of tale bubbling in us. But what we tell is like the middle of a mighty boa, which the foolish forester mistakes for a tree trunk and settles upon to take his snuff. (Achebe 1987:124)

It all began in 1930 in Port Harcourt, Rivers State, part of the then eastern region of Nigeria, when Augustus Ehurie Wogu of Igbo descent and a native of Umuobutu in Old Umuahia became reborn in accordance with John 3:3-8 (General Council Assemblies of God, Nigeria [GCAGN] 1989:6). Following the biblical model (according to Ac 1:8) of beginning from one's home to witness for Jesus Christ, he went back to his village and preached Christ to his people. Due to his preaching, George Mnorom Alioha, Nathaniel Umechuruba, Marcus Asonye, Joseph Asonye, Abel Nwoji, Wilfred Woko, Godwin Akwarandu and many others were converted to Christianity. Augustus and some of his converts devoted their time to reading religious literature that was flooding the country, especially The Pentecostal Evangel, a weekly magazine of the American Assemblies of God. Most of the literature they read carried stories of people who were baptised in the Holy Spirit, with evidence of speaking in tongues (in accordance with Ac 2:4). Wogu and his group sought the gift of the Holy Spirit and received it (Alioha 1984:8). They formed a congregation named 'The church of Jesus Christ' (CJC). The CJC became zealously evangelistic and began to establish branches in the eastern, northern, western, and mid-western regions of Nigeria. The claim by Mugambi (2003:210) that 'the modern Christian missionary enterprise has been an integral part of imperial legacy' did not apply to the CJC, which had African roots since its inception. The story establishes the fact that the Pentecostal outpouring in Igboland and Port Harcourt between 1931 and 1935 preceded the arrival of Pentecostal missionaries from America (Anderson 2007).

The African rootedness of the CJC could, however, not grip its own ecclesiastical soil firmly. The founders exuded a lack of confidence by inviting missionaries of the Assemblies of God, USA to come and take them over and guide them in matters of the Bible, doctrine, and administration. This invitation led to the affiliation of CJC with the Assemblies of God, resulting in a name change from CJC to the 'Assemblies of God, Nigeria' (AGN). Some members of the CJC repulsed the rationale behind the change of their group's name. It was explained to them that the affiliation was done with a people 'who knew better and were more experienced in church administration' (GCAGN 1989:33-34). Further protestations were absorbed and doused with a psychological 
consolation that the affiliation guaranteed to the community access to generous Americans, and has 'united them with myriads of others scattered all over the world under the umbrella of the Assemblies of God' (GCAGN 1989:33-34). An instance of a church that started like the CJC is the Redeemed Christian Church of God (RCCG). The founder of the church, Revd Josiah Akindayomi, was born into a family of idol worshippers in July 1909. Revd Akindayomi started the church in 1952 with seven foundation members. According to the word of God the Holy Spirit revealed the name, The RCCG, to him in a vision. He did not seek for foreign assistance, and today RCCG has grown to a colossus; a church found in every continent of the world. Andrew Rice (2009) describes the RCCG in The New York Times, as 'one of (Africa's) most vigorously expansionary religious movements, a home-grown Pentecostal denomination that is crusading to become a global faith'.

The CJC affiliation with the Assemblies of God, USA carries with it the implication of Nigerianising the leadership of the church. This was a church where all Igbo and non-Igbo members are empowered to take their places in equality and leadership among God's people. With the benefit of hindsight, and recalling the words of Schwarz (1960:4), namely 'it does not take two to make a fight. An idea in the mind of one is enough', the seed-bed for future acrimony in the church was already in the mind. It soon became obvious that the affiliation did not obliterate internalised clan-spirit, identity and the right of ownership of the Assemblies of God that emerged from the ashes of CJC. For a long time the church was referred to as Igbo church in other parts of the country where it found itself. The Assemblies of God thus came into existence in Nigeria in 1939 with the constitutional creation of Igboland District as the first district in Nigeria. The church celebrated its 50th anniversary in 1989. Based on a headcount that was done in 2010, the population of the AGN stands at 2.4 million, with a ministering strength of 11000 pastors (AGN 2010:32-33). The AGN has 74 districts, 6 areas and 14 missionary areas, 10 geographically located Bible colleges, 2 auxiliary institutions and a graduate school for training its ministers (AGN 2010:21). This analysis shows that the AGN become a complex organisation in Nigeria. Managing the objectives of this complex organisation requires the expertise of trained minds with a well-organised administrative architecture.

\section{Ecclesia-political developments in the AGN: Charismatic leadership cum constitution and bye-laws}

The Igbo founding fathers of the CJC, now Assemblies of God, functioned as charismatic leaders and claimed that 'God spoke to them through dreams, prophecies, words of wisdom and words of knowledge' (Favour n.d:xi). The influence of the Holy Spirit helped the founding fathers to function as an egalitarian community, a leadership style that fits well into the Igbo culture, as will be discussed below. However, at the inception of the new church, the missionary Revd W.L. Shirer became the Divisional Supervisor, while
Revd George Alioha was appointed Assistant Supervisor (GCAGN 1989:30). From this point on, one observes that through the influence of American missionaries, democracy was introduced, and constitution and administration became the means through which leadership could emerge. At that time the women department was also organised in the same fashion with operational guidelines and written objectives at the different levels ( GCAGN 1989:32).

In pastoral theology, administration is an essential function of the ministry for the growth and progress of the church. The development of any church organisation is determined by its quality of leadership (Dressselhaus 1979:337). Some churches include the sacred realm of the spiritual as well as the secular realm of the material in their administrative architecture. Since the beginning of the CJC, now AGN, the lives of the members had been the multiple sites for mission, and according to Alioha (1984):

the spread of Assemblies of God in Nigeria was often engineered by the laity, to preach Christ was considered the most precious work a believer could do in his lifetime, for the second coming of Christ was near at hand. (p. 13)

Before the advent of AG missionaries, the CJC had a charismatic-driven ecclesiology in which every member was related to others and the Lord. Alioha (1984) explains that:

all were subject to the Word of God, which was held supreme. No message, regardless of its source, was accepted if it failed to be in harmony with or seemed contradictory to the Bible. (p. 20)

The common bond of brother- and sisterhood in the body of the CJC or AG coalition became strained when 'it was decided that only those who could undergo Bible training would be recognised as pastors' (Alioha 1984:29). Thus, the egalitarian base of the movement that fed the voluntarist principle of engineering mass participation in evangelism faded and became subdued in the missionary and indigenousorchestrated brand of church administration that would later produce a perennial model of adoring loyalty to leadership. The date of entry into the Bible School marked the beginning of the initiation into a full-time ministry, with ordination following in most cases after seven years. The Central Bible College and Institute (now the Assemblies of God Divinity Seminary or AGDS) started from this early Bible study school (Alioha 1984:29).

\section{AGN's understanding of ecclesia- political leadership cum constitution and bye-laws}

To understand the definition of church polity depends on how the AGN defines church. The AGN Constitution (GCAGN 2015:5) states that:

the Church is the body of Christ, the habitation of God through the Spirit, with divine appointments for the fulfilment of her great commission. Each believer, born of the Spirit, is an integral part of the general assembly and the church of the firstborn, which are written in heaven (Eph 1:22, 23; 2:22; Heb. 12:23). (p. 5) 
Vorster (1999) states that church polity merely:

concerns the organisation of the local church and the fellowship of churches in major assemblies in order to realise the rule of Christ as the Head of the church according to the Word of God. (p. 1)

Numerous Early Church documents dealt with stipulations and arrangements based on the apostolic traditions, regarding other aspects of church life. Early ecclesiastical councils made resolutions on how the church should function. There are bound to be tensions between the AGN's biblical ecclesiology and its constitution and byelaws. The side-by-side existence of these two is problematic and bound to produce hypocrisy. On the one hand, the AGN believes that the Bible is the inspired and only infallible and authoritative Word of God and all-sufficient rule for faith and practice' (2 Tm 3:15-17; 1 Th 2:13; 2 Pt 1:21). On the other hand, the AGN says of its Constitution (GCAGN 2015):

WE, THE MEMBERS OF THE ASSEMBLIES OF GOD NIGERIA, a Christian religious body, consisting of people who believe in and are followers of Jesus Christ, DO HEREBY, under God MAKE AND GIVE TO OURSELVES this Constitution and ByeLaws. This Constitution and Bye-Laws is supreme and its provisions shall have binding force on all Members, Churches, Sections, Missionary Areas, Areas and Districts which form an integral part of this organisation and constitute the General Council of The Assemblies of God Nigeria, and in the event of any inconsistency between this Constitution and Bye-Laws of The Assemblies of God Nigeria, with the laws and rules of any arm of this organisation, including and not limited to those already stated, this Constitution and Bye-Laws of The Assemblies of God Nigeria shall prevail, and the laws and rules shall be null and void to the extent of the inconsistency. (pp. 2-4)

In comparison, the Bible is the infallible Word of God, whereas, the AGN constitution and bye-laws is a fallible document. The AGN did not state in its constitution and byelaws any form of church government it subscribes to. It has been observed that AG missionaries from USA who came with a democratic process as well a constitution and byelaws did not understand Igbo culture or the brand of African Pentecostalism they were affiliating with. Kalu (2008:137) documents the fact that 'Pentecostalism cannot generate democracy or serve as a "school" where people learn democratic ways precisely because leaders become controlling and dictatorial'. Becoming 'controlling and dictatorial' would inevitably lead to an ecclesiastical crisis. When this happens, what takes pre-eminence: the Bible as the Word of God or the church's constitution and bye laws? In such a situation it becomes pertinent to root for theological convictions, and a sound theoretical base anchored on a constitution that recognises a holistic view of human nature, culture, equality and social justice. It also requires a defined constitutional process by which leaders emerge and leave office at the expiration of a stipulated tenure. Furthermore, it entails a clear understanding of mission objectives, power concepts and ecclesia-political leadership in relation to inherent human inadequacies
The GCAGN (1989:98) aver that before CJC became the AGN, it governed in a unitary, Presbyterian form of church government that has remained the characteristic feature of the present-day AGN administrative structure. The added sophistication is that presently, the AGN operates a four-tier, bottom-up Presbyterian formal structure in the following manner: firstly, the local churches; secondly, the sections; thirdly, the district council or missionary areas; and fourthly, the general council at the apex. Offices and departments are almost uniformly distributed from top-down instead of from bottom-up in a manner reminiscent of Presbyterianism. One wonders how this arrangement resembles a Presbyterian form of church government at all. In the AGN, ascension to the top-levels of leadership thrives on the Igbo culture of competitiveness, and this is because the top is really powerful, whereas the base is powerless.

\section{The Igbo phenomenon in AGN: Unity, disunity and leadership}

Unlike the Kikuyu of Kenya who are bound by one mother, $M u m b i$, the Igbo do not claim descent from or access to a common matrilineage. The Yoruba are bound by a story of one progenitor, Oduduwa, but the Igbo are reputed to have none. The Zulu people of South Africa claim to be Amazulu, a united people from the sky, but there is no single story about the origin of the Igbo. According to Achebe (2000):

the Igbo people are not linked by blood ties, although they may share many cultural traits; Igbo people do not speak one dialect; they speak one language which have scores of major and minor dialects; and as for having one recognized leader, Igbo people would regard the absence of such a recognized leader as the very defining principle of their social and political identity. (p. 4)

In another context, Achebe (2012:246) says that 'the Igbo are a very democratic people. The Igbo people expressed a strong antimonarchy sentiment - Ezebuilo - which literally means, a king is an enemy'. The presupposition is that Achebe (1983:46) has artistically packaged the motley Igbo egalitarian structure with its marked individualistic and antagonistic landscape in our socio-political world. If by 'Igbo are democratic', Achebe means the form of government that favoured the execution of Socrates in Athens, called by Plato (1955:330-331) a decadent form of government, 'an agreeable, anarchic form of society ... which treats all men as equal, whether they are equal or not', the author is absolutely correct. Scholars who are familiar with the Igbo context would judge that Achebe has deliberately ignored various theories of democracy in desperation to showcase the Igbo as a people with a natural predilection for democratic practice. Precolonial Igbo though are not known as a people who sought the consent of one another, or made their political choice through voting processes and then obeyed a chosen government of their own making.

A brand of democracy that is capable of flourishing among the Igbo is one that admits the inseparability of political and economic powers. Any form of a unifying static democratic body, divorced from economic incentives, finds no lodging 
among the Igbo (Irukwu 2007:14). Furthermore, the individualistic temperament of the Igbo, engineered by a cultural emphasis on individual achievement, is a major contributory factor to the apparent fragmentation of the people (Coleman 1965:28). Achebe portrays a heightened culture of competition among the Igbo in most of his books, especially in his widely-read book, Things fall apart (1958). In this work, Achebe illustrates an Igbo culture of 'challengeriposte' (Malina \& Neyrey 1991:25) in which the victories of Okonkwo and those who mimicked him, deprived others, 'the vanquished', of their honour. In other words, in most of his works Achebe rightly describes the Igbo as a people who have imbibed the perception of limited goods and space. Such a society as the Igbo, according to Malina and Neyrey (1991), naturally 'institutionalises envy even among friends, especially among equals'. And the end result is:

a zero sum game in which the winner takes all, while crowds look on and congratulate the winner, all the while hoping that they themselves might be in the winning position and envying the winner's success. (p. 31)

Evidently Achebe (2012:74) plays down the inherent contradiction in Igbo culture when he says that the Igbo culture, being receptive to change, individualistic and highly competitive, gave the Igbo man an unquestioned advantage ...'. This is contra the general perception, according to Aneke (2014) that:

divisiveness and disunity are the greatest bane of the Igbos, by reason of which they have been ridiculed, cajoled, left behind in the scheme of things both in Nigeria and around the world, and accomplished nothing tangible in the last fifty years.

In a conversation with Orabuchi (2016), Chief Sabi Nweke precociously summarised the Igbo dilemma as 'selfishness, individuality, continuous internal fights, and failed leadership'. The Igbo culture and people, as analysed above, best portrays the characteristics of a noyau culture that is described by ethnologists as a society of people or 'animals that exhibit inward antagonism, often held together by mutual internal antagonism, and could hardly survive if its members had no fellow members to hate' (Chinweizu 2005).

Furthermore, European missionaries used education to convert a large population of the Igbo to Christianity. Because education encouraged individual performance and recognition, the majority of the Igbo embraced it. In the realm of Nigerian politics, the Igbo, who were segmentary in their social organisation, complicated the task of being welded into a united Nigerian nation (Coleman 1965:52). In this regard, pre-independence British administration in Nigeria made every effort to induce Igbo clans to federate and establish clan, district, or divisional councils ( $\mathrm{O}^{\prime}$ Connell 1967:129). Another pertinent factor has to do with blood relationship, an aspect that will be discussed below. In a laudatory manner, Achebe (2012:74) says that 'the Igbo was unhindered by a wary religion. The Igbo was unhampered by traditional hierarchies'. This kind of creature - the Igbo -: fearing no god or man, was custom-made to grasp the opportunities, such as they were, of the white man's dispensations. The Igbo wiped out their handicap in one fantastic burst of energy in the twenty years between 1930 and 1950 . (Achebe 2012:74)

Coincidentally, the period from 1930 to 1950 was the peak of the missionary activities of the CJC that metamorphosed into the AGN.

Before 1934, Old Umuahia and its neighbouring towns were evangelised resulting in churches being planted. In 1935 two churches were planted in Enugu and by 1937 a group that transformed into a church was founded in the Eko Ewu-Ishan Division, in mid-western Nigeria. From this single church, six others were established between 1943 and 1944. From 1938 onwards churches were founded in northern Nigeria, namely in Kafanchan, Kaduna, Kano and Zaria. Following the establishment of these four churches, others were founded in Lafia, Sokoto, Gusau, Maiduguri, Gyom and many other towns. A number of Igbo members of the Assemblies of God began a new church in Ibadan in 1948-1949, and by 1953 a full-time pioneer pastor was transferred to Ibadan. The Igbos is a prolific and versatile people found in every aspect of human endeavour in the country. O'Connell (1967:135) says of the Igbo in northern Nigeria that they 'kept a tight grip on the lower posts of the administration so that even when qualified Northerners began to become available, they found it difficult initially to break the Ibo monopoly'. According to Coleman (1965:76) the 'Ibos constitute more than one-third of the non-indigenous population of the urban centres in the Northern and Western regions'. Anber (1967) observes that:

educational and economic progress of the Igbo led to their becoming the major source of administrators, managers, technicians, and civil servants for the country, occupying senior positions out of proportion to their numbers. (p. 165)

This background history illustrates why it was possible for the Igbo of the Assemblies of God to establish, pioneer, and function as leaders of these churches in districts and regions far away from their own native region.

\section{No blood ties linking the Igbo}

Achebe (2000:4) says that 'Igbo people are not linked by blood ties, although they may share many cultural traits; they speak one language'. This statement weakens the form of similarities and dissonances among the Igbo, where the lineage father determines uтипna-papa's children wherever they may be found. The concept of umunna suggests patrilineage that narrows down, but expands from family father to tribal father, to clan father, to village father and to the larger Igbo group as a nation. Any gathering of the various groups at any level is what is called an umunna meeting, which traces its binding force to language rather than blood ties or patrilineality. Pantaleon (1996) says that:

wherever the Igbo are found, they form a non-blood or nonancestor-related umunna. In this case, language plays an important role. Language binds them together, just as the Word of God binds Christians. (p. 89) 
Achebe (2012:75) outlines the Igbo culture of 'competitiveness, individualism, adventurous spirit, exhibitionism, and disregard for humility, self-confidence and belief that one man is as good as another'. What is the implication of these cultural traits for the Igbo in the realms of the secular or the sacred? Does it create fear that such a people would not make good followers or team-players in any society or organisation that has a defined agenda and corporate goal? How then did the Igbo fit into the frontline burner of the Christian religion with huge success in establishing churches and mission fields all over Nigeria?

The Christian religion that the Igbo embraced thrives on God's Word that has the power to weld disparate and diverse peoples together as a community of King-Jesus. Firstgeneration Christians in the AGN were bound by the Word, and known to be people of the Spirit. Perennial themes of Christian doctrine such as Christology, pneumatology, ecclesiology and eschatology functioned and crowded out primitive worldviews that were anchored on 'worldly ambition'. At that time the fundamental ideological paradigm of the AGN was erected on pneumatology, eschatology, and in terms of praxis, evangelism. These had remained in the foreground of the church's immediate and long-term goals. The AGN prospered under the power and influence of the Holy Spirit. A born-again Igbo in the AGN would interpret the Igbo worldview of 'competitiveness, individualism, and disregard for humility' as part of the fallen world and depraved human nature, and sees 'the old creation has gone; all things have become new' (1 Cor 5:17) in the body of Christ. In Christ life is lived in totality, not individuality; Christian life is an orchestration of all humanity in Christ. Thus, the church is the body of Christ on earth. These first-generation born-again Igbo Christians were inspired by the love of God and the ideal to act like Christ to realise to the full the purpose for which God had made them a new creation in Christ (Latourette 1975:213). Thus, they acted selflessly when they invited the American missionaries to Nigeria to help them affiliate the CJC with the Assemblies of God, USA. From missional perspective they considered it worldly to critically ponder the leadership implications of such an affiliation because God's work was of the utmost importance. Thus, by '1939, the CJC lost its name to Assemblies of God Mission' (GCAGN 1989:78), and became what Anderson (2007:169) calls classical Pentecostals originating in Western Pentecostal missions. In other words the CJC died as an indigenous church to become AGN with the features of national cum international characteristics that breaks loose from the bonds and boundaries of locality. Furthermore, the winning of the professed allegiance of the overwhelming majority of the non-Igbo to Christ meant that leadership in the AGN would no longer be confined or localised, but distributed and universalised. From henceforth the missionaries functioned as national superintendents, heads of Bible schools, and strategic thinkers for the administration of the church offices that were primarily meant for service.

With the growth of the church and creation of administrative districts, areas and sections, the emergence of Igbo leaders nationwide became obvious. The overwhelming majority of non-Igbo population in the AGN were beginning to perceive a systemic absence of equality, equity, fair play, justice and righteousness. Aja (2006:109-114) was quite cautious and uncritical in treating this important aspect in his crafted book, The history and polity of Assemblies of God, Nigeria. It is pertinent to note the degree of Igbo urbanisation outside Igboland in non-indigenous population in the 1950s. Paraphrasing Coleman (1965:77) the following statistics could be drawn: In the city of Lagos the indigenous group is the Yoruba, but of all non-indigenous groups the Igbo population was $44.6 \%$. In Benin City the indigenous group is Edo, whereas of all nonindigenous groups the Igbo population was 53.5\%. In Sapele the indigenous group is Urhobo, whereas of all nonindigenous groups the Igbo population was $46.6 \%$. In Calabar the indigenous group is Efik, whereas of all non-indigenous groups the Igbo population was 50.7\%. In Kano the indigenous group is Hausa, whereas of all non-indigenous groups the Igbo population was $38.0 \%$. In Zaria the indigenous group is Hausa, whereas of all non-indigenous groups the Igbo population was 39.0\%. Kaduna was a mixed population and the Igbo population was $40.7 \%$. These figures are important, not only to realise the widespread urbanisation of the Igbo peoples, but also as partial insight into their vanguard role in the missionary expansion of the AGN. The Igbo held the top-level positions of leadership in almost all the districts. Thus, when ordained indigenes began to become available, they found it difficult to break the Igbo hegemony.

From 1939 to 1961 American missionaries governed the AGN as General Superintendents, namely Revds Lloyd Shirer, Everette Philips, Clarence Goudie, Elmer Frink, Rex Jackson, Harry Pennington and Robert Carlson. Aja (2006:100) claims that the 'Assemblies of God Nigeria practices a combination of two systems of church government: the congregation and Presbyterian'. He does not explain the pneumatological mystery of this combination and how they simultaneously adhered to the authority of the Bible, though. He captures the pneumatological determination of the early indigenous leaders to manipulate the constitutional bye-law's provision of a four year tenure in the office as District Superintendent (Aja 2006:102). 'The Bye-Law provision that granted a maximum mandate of four years in office' was amended by Revd John Nwakanma while occupying the office to read that any occupant of the office remains in it 'as long as the Lord wills' (GCAGN 1989:79). Thus, from 1953 to 1986 Revd Nwakanma continued to serve as District Superintendent for 30 years. Subsequent leaders followed suit as the AGN's constitution remained silent on the number of tenures that elected officers should remain in office. The General Superintendent of the AGN, Revd G.O. Oyakhilome, a nonIgbo, stayed in office from 1966 to 1982 and then retired. Revd Matthew Ezeigbo, an Igbo, served as General Superintendent and stayed in office from 1982 to 1988, and retired. Revd Dr Charles O. Osueke, an Igbo, became the General Superintendent from 1988 to 2010 and retired at the statutory age of 70. Revd Dr Paul Emeka, an Igbo from Enugu state, was elected as General Superintendent at the 34th General Council of the AGN in November 2010. It is pertinent 
to know that the AGN's constitutional age of retirement is 70 years. It is presumed that Emeka was officially in his early 60s when he was elected as the General Superintendent, while his assistant Revd Dr Chidi Okoroafor, an Igbo from Abia State, was in his mid-50s. If the pattern of length of service by his predecessors was anything to go by, Emeka was expected to stay in office until 'the Lord wills', which would be at the time of his retirement, an age which might not give much room for his assistant to assume office as the General Superintendent all things being equal.

After barely three years in office, troubles began in September 2013 when a body of the laity in the church, called 'The Ambassadors', wrote a petition against some of Emeka's practices. The five-page petition, dated September 2013, was signed by 12 members of the body, mainly Igbo. It was addressed to all district presbyteries of the AGN and accused Revd Emeka of high handedness, financial mismanagement and abuse of office. Emeka, they claimed, had arrogated too much power to the self and operated like a General Overseer or Founder. They accused him of spending over 250 million naira on the purchase of a building in Germany without the approval of the Executive Council (EC), as well as misappropriating another 200 million naira from the Pension Fund without due process. He was also accused of introducing alien cultures into the church: one of them was wearing 'big rings on some fingers of both hands'. This practice, The Ambassadors said, was at variance with what the church stands for. They alleged that the practice has been adopted by many upcoming ministers, dubbed the 'GS boys', in the church and that Emeka had created a universal impression that he is the General Superintendent (GS) as well as the General Overseer (GO) and the physical personification of the AGN. The GS has thus arrogated to himself a position that is superior and above the General Council and the EC combined.

Furthermore, they alleged that Emeka wanted latitude to act without being checked and wielded executive powers without consultations. They accused him of living in opulence and wasting the church's resources for personal aggrandisement, especially when travelling overseas; he allegedly spent $\$ 6000$ on a luxury wrist watch in London during a shopping spree. Despite the existence of a palatial office complex for him in the Evangel House (the administrative headquarters of the AGN), he also built another 'befitting personal office edifice' in Enugu. All these acts, they alleged, angered many leaders and members of the church. In the heat of all these allegations, Emeka lost the support of 11 members of the EC and deliberately stayed away from the convocation of the General Committee (GC) where these issues and many others could be thrashed out. $\mathrm{He}$ also called the convocation illegal and tried to obtain a court injunction to stop the GC's meeting. At that point, the deliberations became volatile and the suspension of Emeka was pronounced under the watch of Revd Dr Charles Osueke, the retired GS who chaired the deliberations. Emeka's Assistant General Superintendent (AGS), Revd Dr Chidi Okoroafor, an Igbo who had been at loggerheads with him, was pronounced the acting General Superintendent with immediate effect. Emeka went to court to challenge his suspension on the grounds that the AGN has never used votes to decide on the suspension or punishment of an erring member. He alleged that the retired GS, Osueke, an Imo State indigene, was using promotional efforts to impose Okoroafor, an indigene of Abia State, on the AGN, an act that he would never accept. Thus the national church (the AGN) split into two with one group supporting Emeka and another group supporting Okoroafor.

Presently the AGN is at orita and it is hard to predict the vivid image of the portentous nature of the survival of the next generation of the church. Orita is a Yoruba word meaning junction(s) or crossroads. It is a place where two roads cross at (or about at) right angles, otherwise known as 'the fork in the road'. Metaphorically in most parts of Africa orita has functioned in the rubric of religious and folkloric belief and is traditionally considered a suitable site on which to perform sacrifices, and magical rituals, and cast spells. At orita every traveller or pedestrian must make a choice on where to turn, and there are questions that people ask at the orita. Being at the orita, there are questions that the AGN must now ask itself: The first is a question from ontology: Is the AGN's problem a purely Igbo phenomenon? Secondly, does the problem have to do with the locus of authority, namely the Bible, the Word of God, or the AGN's constitution? Thirdly, is it a problem of the African worldview of honour-shame culture? Fourthly, is it a problem of identity crisis resulting in a loss of an eschatological, ecclesiastical cum pneumatological paradigm? Fifthly, is the problem a combination of all these? The best attempt at answering these questions is to begin with the fourth question regarding a loss of eschatology, ecclesiology and pneumatology.

At orita the AGN is reminded that eschatology is all about the coming kingdom of Jesus Christ. It is about a heavenly kingdom of which the Lord counselled his listeners to:

store up for yourselves treasures in heaven, where moth and rust do not destroy, and where thieves do not break in and steal. For where your treasure is, there your heart will be also. (Mt 6:20-21)

It is not about this present world of which Peter spoke, saying 'the earth and everything in it will be laid bare or be burned up' (2 Pt 2:19b). The earnest expectation of the kingdom of Jesus Christ is what binds a people together in one body called the church, where the individual believer is the church (1 Cor 6:19), the local congregation is the church (1 Cor 3:17), and the universal church exists (Eph 2:19-22). The church is one united fellowship, because it transcends national and racial differences as well as social inequality. Love is the hallmark of the church and it bridges cultural separations and doctrinal differences.

There are various forms of ecclesiastical government. Erickson (1998:1080) mentions the following prominent ones: Episcopal government in which the bishop rules; Presbyterian government in which authority is vested in the presbyters or elders of the church; Congregational government in which the authority of the congregation is recognised; and Charismatic 
government in which authority flows from the charismatic leader. However, it is not possible for any of these forms to enhance Christian unity in Igboland where power, honour and shame are basic indices of the culture. The third question at orita has to do with the African worldview of power, honour and shame. In African culture every power has a visible as well as an invisible pole, most of which are vested in individual figures in the church or any given community (Kalu 2008:181). The language of power pervades the whole of Africa and is manifested in men in political, ecclesiastical, spiritual and structural forms. In Africa especially among the Igbo, power is attached to honour and shame, so that almost every relationship is interpreted, according to Achebe (2012:75), along the lines of competition in which 'one man is as good as another', thus, under the compulsion of their culture, the Igbo are 'pantomimic gentlemen who are so clever that they can imitate anything' (Plato 2000:69) in the bid to be 'as good as anyone'. It is a culture that is counterproductive; it creates unfulfilled psychological leverage, mediocrity and an inner reluctance to appreciate the beauties and specialities of the next-door neighbour. The self and nothing else is the standard for everything. Achebe (2012:74) describes the Igbo as a 'kind of creature, fearing no god or man', and without respect for space or boundary. It is this kind of culture that is responsible for the non-inclusion of a limited tenure of office in the AGN constitution and bye-laws. To be voted out of office in an election is to suffer humiliation in a competition, and supporters would say: 'shame must not catch us'. Thus, the struggle to always be in office 'as long as the Lord wills' causes others to wait for their turn or fight for their space through covert promotional efforts.

The second question at orita points to the AGN constitution and bye-laws as one of the causes of the present crisis, as it does not specify a mandatory number of terms that an elected officer should remain in office. The constitution does not specify that the offices of the 'four generals' (General Superintendent, Assistant General Superintendent, General Secretary, and General Treasurer), should be rotated throughout the 11 zones of the country to accommodate the minority population within the church polity.

The first questions at the orita are: 'What is the cause of the AGN systemic crisis?', and 'Are the Igbo responsible for this crisis?' To situate these questions in context, the Federal Government of Nigeria created five states for the Igbo people, namely Abia, Anambra, Ebonyi, Enugu and Imo. What has been observed over time, according to Anele (2015), is that:

in the civil service and educational institutions up to the university level, people from different parts of the same state discriminate and fight among themselves. Sometimes, an application for employment or promotion is rejected because the person is from Imo State rather than Enugu state, and vice versa.

In a similar context Nnanna (2012) writes how a former Chief Justice of Nigeria, Aloma Mariam Mukhtar, declined to swear in Justice Ifeoma Jombo-Ofor one of 12 newly appointed Justices of the Federal Republic of Nigeria, as a Justice of the Appeal Court. The apparent basis was that Justice Jumbo-
Ofor could not represent Abia State, as she hails from Anambra State. Her husband, however, hails from Abia State and she has served in the Abia State Judiciary for 14 years. Anele (2015) laments:

The Igbo not only fight themselves in Igboland; some of them, for selfish reasons, exhibit excessive competitiveness in other parts of the federation. In the North and South-West, there are incidents of unhealthy rivalry between Igbo individuals and groups, each trying to outdo the other, using Machiavellian tactics, generating unnecessary animosity in the process.

A Catholic Bishop, Peter Ebere Okpaleke, who hails from the Awka in Anambra State, was rejected at Ahiara in Imo State because he is not an ethnic Mbaise. Bunderson (2013) reports that:

the Catholics of the diocese wanted one of their own to be appointed bishop over them. In the face of division among the Igbo, brought to light by the controversy over Bishop Okpaleke, there has been a call for greater Igbo unity and identity.

In 2011 the former governor of Abia State, Theodore Orji, sacked employees from other Igbo-speaking states - an action that 'demonstrates that Ndigbo are their own worst enemies' (Anele 2015). These examples serve to illustrate one of the causes of the present ecclesiastical crisis in the AGN of which two Igbo men are the protagonists. The general perception has been that the suspension of Emeka is part of the intra-Igbo rivalry, for the members of the Ambassadors who initiated the protest against Emeka are from the same axis of Igboland. Supporters of Emeka therefore consider his suspension as unchristian, unconstitutional, and humiliating to that office. Almost all non-Igbo ethnic groups in and outside the AGN are ambivalent about the crisis, calling it 'a purely Igbo affair' to which they have been unwittingly drawn. They are of the opinion that the disruption of the ecclesiastical order of a community that once lived in harmony is engineered by the competitive worldview of the Igbo ethnic group. The best way to survive is to remain with the perceived winning side, or crisscross the party lines to exploit the fortunes of the leadership crisis.

\section{Conclusion}

In the final analysis the conclusion must be drawn that not one factor is responsible for the crisis in the AGN. It is a conglomeration of the factors identified above. The Igbo factor remains a strong one in the issue at hand. The eschatological, ecclesiological and pneumatic heritage of the church has been eroded. Furthermore the constitution and bye-laws within the fellowship by which the strong individualistic tendencies of the Igbo could be ameliorated for the common good has equally proved ineffective. It is obvious that there is a fundamental loss of the momentum that propelled the founding father of CJC to relinquish power to the missionaries for the common good of the movement. The momentum consisted of perception of kinship ties with 'foreigners' on the basis of belonging to a common Father. The momentum consisted in a gripping understanding that 
the 'end was near'. The momentum consisted in reliance on the Spirit to forge true unity. The momentum consisted thus in an unwavering commitment to the task of evangelism for the sake of which all personal ambitions were held in check. However, in instances where human frailties and weaknesses seek to emasculate these elements of a common heritage, a constitution that is far-reaching enough to check human excesses comes to the rescue. The outcome of the present crisis is that the failure of the internal means of cleansing, revival and rejuvenation has brought the church to rely on arbitration by a worldly Supreme Court to bring succour and direction to a church at orita.

\section{Acknowledgements \\ Competing interests}

The author declares that he has no financial or personal relationships which may have inappropriately influenced him in writing this article.

\section{References}

Achebe, C., 1958, Things fall apart, Heinemann, Nairobi.

Achebe, C., 1983, The trouble with Nigeria, Heinemann, Harlow.

Achebe, C., 1987, Anthills of the savannah, Heinemann, Nairobi.

Achebe, C., 2000, Home and exile, Anchor Books, New York.

Achebe, C., 2012, There was a country: A personal history of Biafra, Penguin Books, New York.

Aja, D.N., 2006, The history and polity of Assemblies of God, Nigeria, Iperu, Nigeria.

Alioha, G.M., 1984, The grain of mustard seed: The history of Assemblies of God, Nigeria, Assemblies of God Press, Aba.

Anber, P., 1967, 'Modernisation and political disintegration: Nigeria and the Ibos' Journal of Modern African Studies 5(2), 163-179. http://dx.doi.org/10.1017/ S0022278X00019078

Anderson, A., 2007, Spreading fires: The missionary nature of early Pentecostalism, Orbis, Maryknoll.

Aneke, L.N., 2014, 'Ndi Igbo at the crossroads tackling the problems of Igbo divisiveness \& disunity', viewed 5 March 2016, from http://nigeriaworld.com/ feature/publication/aneke/111408.html

Anele, D., 2015, 'How Ndigbo underdeveloped Igboland', viewed 28 June 2015, from http://www.vanguardngr.com/2015/06/how-ndigbo-underdeveloped-igboland
Assemblies of God, Nigeria (AGN), 2010, Current facts, Diamond Press, Enugu.

Bunderson, C., 2013, 'Nigerian bishops lament disunity among local Catholics', Catholic News Agency, viewed 21 July 2015, from http://www.catholicnewsagency. com/news/nigerian-bishops-lament-disunity-among-local-catholics

Chinweizu, 2005, 'The reconstruction of Nigeria: Four delusions on our strategic horizon', The Guardian Newspaper, viewed 12 July 2015, from http://www. guradiannews.com

Coleman, J.S., 1965, Nigeria: Background to nationalism, University of California Press, Oakland.

Dressselhaus, R.L., 1979, 'The pastor and total church leadership', in T.F. Zimmerman, G.R. Carlson \& Z.J. Bicket (eds.), And He gave pastors: Pastoral theology in action, pp. 337-368, Gospel Publishing House, Springfield, MA.

Erickson, M.J., 1998, Christian theology, 2nd edn., Baker Books, Grand Rapids, MI.

Favour, A.-O., n.d., A biography of Rev. Dr. Augustus O. Asonye, s.l., Umuahia.

General Council of Assemblies of God, Nigeria (GCAGN), 1989, The growth of Assemblies of God in Nigeria, Assemblies of God Press, Aba.

General Council of Assemblies of God, Nigeria (GCAGN), 2015, Constitution and byelaws, Assemblies of God Press, Enugu.

Irukwu, J.O., 2007, Nation building and ethnic organisations: The case of Ohanaeze in Nigeria, Spectrum Books, Ibadan.

Kalu, O., 2008, African Pentecostalism: An introduction, Oxford University Press, New York.

Latourette, K.S., 1975, A history of Christianity: Beginnings to 1500, vol. 1, Prince Press, Peabody.

Malina, B.J. \& Neyrey, J.H., 1991, 'Honor and shame in Luke-Acts: Pivotal values of the Mediterranean world', in J.H. Neyrey (ed.), The social world of Luke-Acts: Models for interpretation, pp. 25-66, Hendrickson, Peabody.

Mugambi, J.N.K., 2003, Christian theology and social reconstruction, Acton Publishers, Nairobi.

Nnanna, O., 2012, 'Justice Jombo-Ofo and the tragedy of Nigeria', The Guardian Newspaper, viewed 12 November 2012, from http://www.vanguardngr.com/ 2012/11/justice-jombo-ofo-and-the-tragedy-of-nigeria

O'Connell, J., 1967, 'Political integration: The Nigerian case', in A. Hazlewood (ed.), African integration and disintegration: Case studies in economic and political union, pp. 129-184, Oxford University Press, New York.

Orabuchi, A., 2016, 'Ndi-lgbo: Past, present, future - What is your fate?', viewed 5 March 2016, from http://obindigbo.com.ng/2016/01/ndi-igbo-past-presentfuture-what-is-your-fate

Pantaleon, O.I., 1996, Appropriate ecclesiology: Through narrative theology to an African church, International Universities Press, Owerri.

Plato, 1955, The Republic, transl. H.D.P. Lee, Penguin, London.

Plato, 2000, The Republic, unabridged, transl. B. Jowett, Dover Publications, New York.

Rice, A., 2009, 'Mission from Africa', New York Times, viewed 21 May 2016, from http://www.nytimes.com/2009/04/12/magazine/12churches-t.html?_r=0

Schwarz, F., 1960, You can trust the communists to be communists, Prentice Hall, Long Beach.

Vorster, J.M., 1999, An introduction to reformed church polity, Potchefstroom Theological Publications, Potchefstroom. 